\title{
Migration background and educational affordability amongst Pacific Islander migrant learners in Melbourne's western region
}

Irene Kmudu Paulsen

University of Auckland

\begin{abstract}
High cost is a major barrier to the attainment of educational goals of many learners, especially those from economically-disadvantaged backgrounds. In Australia, this cohort includes Pacific Islander (PI) learners for whom low family income and ineligibility to access Government assistance for tertiary education costs may prohibit some learners from pursuing Higher Education (HE) studies. Whilst cultural barriers such as unfamiliarity with the education system, low language competence, and poor institutional support for non-traditional learners have consistently dominated the discourse on Pacific Islander learner's low levels of achievement in education, less attention has focused on the effects of migration background, economic, and social adjustment patterns on their schooling outcomes. This article proposes that migration history, socio-economic background, and financial challenges affect PI migrant learners in two distinct ways: for those who have motivation and capability to enroll in tertiary level study, their aspirations are constrained by the high cost of tuition fees; while those learners who have the financial means and support to enroll in HE study are sometimes constrained by long-term poverty, which affects their motivations to study at the tertiary education level.
\end{abstract}

This qualitative study involved working with a small group of PI learners from Melbourne's western region from 2012 to 2015. Information was gathered from semistructured interviews conducted with learner participants, and their parents and teachers. Learners were interviewed three or four times, while their parents and teachers were interviewed either once or twice over a four-year period. The collected data was sorted and categorized using NVivo software, and later categorized into broad themes, which were then cross matched with individual learner case stories to refine emerging finding and themes.

The study revealed that migration background has an important influence on the social and economic settlement patterns of PI learners and their families and these in turn significantly affect learners' schooling and post school outcomes.

Keywords: Pacific Islander learners; migration background; school outcomes

\section{Introduction}

The relationship between cost and education has dominated the discourse on educational participation and achievement for many decades (Connell, 2003; Marginson,1999). High cost

Corresponding author: Irene Kmudu Paulsen (i.paulsen@auckland.ac.nz) 
or inability to afford education can be a serious barrier to school participation, achievement and outcomes for some groups of learners, particularly for those from low socio-economic backgrounds, including from immigrant, refugee or indigenous communities. For many migrant groups in Australia, much of their participation in education, especially at the post-compulsory and tertiary education levels, has been marked by consistent under achievement and low-level participation with subsequent limited opportunities for career-related and sustainable employment, leading to low level engagement and adjustment to broader Australian society by certain groups (Chenoweth, 2014; Kearney, 2012; Kearney \& Glen, 2017; Singh \& Sinclair, 2000; Vasta, 2004).

Many Pacific Islander ${ }^{1}(\mathrm{PI})$ migrants view education as both a process and outcome that is an effective motivation and indicator of the level of success that individuals and families can achieve through the migration process (Ravulo, 2015). Successful schooling and the achievement of positive pathways to Higher Education (HE), training and career-related employment are seen as valuable and worthwhile investments for personal and collective benefits to individuals, families and communities (Paulsen, 2016; Ravulo, 2015). When viewed through a social, cultural and economic lens, migration is seen to be a worthwhile undertaking, even if difficult and arduous, which can provide access to various forms of capital (Bourdieu,1997), including improved educational opportunities and benefits.

In Australia, the senior secondary school comprises the final two years of post-compulsory schooling and marks a period when learners begin to consider pathways to HE, training or employment. Cost becomes an important consideration for some PI learners and their families in the decision to continue or withdraw from further study (George \& Rodriquez, 2009; Rose, Moore \& Quanchi, 2009). The post-compulsory stage of schooling can be a vulnerable time for many young people as their physical and emotional independence increases and they become more self-aware of the opportunities or limitations that can affect the choices they make about their futures (Bourne, 2008). For some PI learners, this is a particularly difficult time as the choices made can have broad implications and consequences not only on themselves and their education or employment goals, but also on the socio-economic wellbeing of their families and their extended cultural communities (Fairbairn-Dunlop, 2010; Samu, 2007; Thaman, 2008).

This paper looks specifically at the intersections between migration history, socio-economic background, and financial unaffordability amongst PI families, and the consequences of these factors on the educational experiences and transitions of a group of second-generation PI migrant learners living and studying in Melbourne's western region from 2012 to 2015. It argues that migration history, socio-economic circumstances, and financial unaffordability, whether individually or collectively, can significantly affect a learner's aspiration to access further or tertiary level education. It further contends that a family's economic and financial situation significantly influences learners' choices about future school pathways. Low academic achievement and continuous experience of financial stress at home also contributes to early school withdrawal by learners who may already be dis-engaging at school. Additionally, long term poverty can result in lowered motivations for tertiary study by learners who may view HE studies as being difficult, take too long to complete, or to interfere with family priorities.

At the 2011 Australian census, PI comprised about $1 \%$ of the national population, with New Zealand Maori, Polynesians, Melanesians and Micronesians accounting for approximately $45 \%, 38 \%, 15 \%$ and $0.4 \%$ respectively (Ravulo, 2015). Most Polynesians were recorded as

\footnotetext{
1 Pacific Islanders (PI) refer to the diverse communities of people who come from the many island countries in the South Pacific, including Melanesia (Papua New Guinea, Fiji, Vanuatu, Solomon Islands, New Caledonia), Polynesia (Samoa, Tonga, Cook Islands, Tuvalu, Niue, Hawaii, French Polynesia, Tokelau) and Micronesia (Kiribati, Guam and Nauru, Marshall Islands).
} 
being of Samoan, Tongan and Cook Islander backgrounds, while Fiji and Papua New Guinea comprised the two largest Melanesian groups. The Nauruans made up the biggest Micronesian group. The number of PI migrants to Australia has steadily increased, with PI making use of various migration pathways to legally enter, live and work in the country (Pryke, 2014; Woolford, 2009).

Many PI of Polynesian heritage have generally entered Australia through their citizenship rights in New Zealand, facilitated originally through citizenship by birthright (Cook Islanders, Niueans and Tokelauans), guest worker schemes (Tongans and Tuvaluans), and a long-term bilateral agreement between the New Zealand and Samoan Governments to provide resident access to some 1000 Samoan migrants each year (Hamer, 2014). Such initiatives for residence or citizenship rights in either New Zealand or Australia were not normally extended to PI Melanesians and Micronesians. The pattern of permanent migration for these two PI ethnic groups reflect more recent arrivals (last forty years) using either skilled, guest-worker or familysponsored pathways (Pryke, 2014) to enter, live and work in Australia.

PI Polynesians in Australia who are also New Zealand citizens are governed by special migration legislation that apply to all New Zealand citizens. Since the Trans-Tasman Travel Arrangement (TTTA) in 1973, Australia and New Zealand citizens have travelled freely between the two countries and can reside temporarily or permanently in each country. Many PI Polynesians who had become New Zealand citizens due to visa rights with their respective Pacific countries were able to also travel to and live permanently in Australia under the TTTA (Bedford, Ho \& Hugo, 2003), despite it being referred to as a 'back-door' route to Australian migration (Hamer, 2014; Spinks \& Klapdor, 2014). Nevertheless, the number of New Zealand PI moving to Australia continues to increase due to its mutual open-door policy for residence purposes. However, there are restrictions applied on social security rights and benefits, including access to educational benefits, depending on which country they choose to reside in, with Australia exercising stricter regulations on its residents compared to New Zealand (Hamer, 2014; Spinks \& Klapdor, 2014).

In September 1994, Australia introduced new legislation requiring all non-citizens to hold valid visas to reside in the country. New Zealand citizens, including PI, were required to hold a Special Category visa (SCV), which allowed free entry to Australia based on a valid passport and satisfactory health and character checks. Under this visa, this group could live permanently in Australia and have access to certain social security benefits. However, an amendment to the Australian Citizenship Legislative instrument in February 2001 placed further restrictions on the social rights of New Zealanders in Australia, including the removal of rights for SCV holders arriving from February 2001 onwards to apply directly for Australian citizenship or to access support for tertiary study (Chenoweth, 2014).

In December 2015, the Turnbull Government passed the Higher Education Legislation Amendment (Miscellaneous Measures) Act, which gave New Zealand citizens who had arrived in Australia after February 2001 access to the Higher Education Commonwealth SupplementHigher Education Loan Program (HECS-HELP2), as long as they held an SVC visa and entered Australia as a dependent minor under 18 years of age. They also had to have been resident in Australia continually for approximately ten years. The downside of this change was that New Zealand citizens could no longer access HELP loans if they apply for and are granted permanent visas (such as skilled or family sponsored visas) as a means to acquire citizenship.

These ongoing changes have had quite serious implications on New Zealanders, particularly New Zealand Maori and PI's ability to access social security benefits, including eligibility for

\footnotetext{
2 Financial assistance provided by the Australian Government in the form of a loan to meet university or Technical and Further Education (TAFE) tuition costs. This loan is repaid to the Government once the student starts employment and earns an amount of AUD $\$ 55,000$ or more per year (in 2016). This threshold amount was adjusted to $\$ 42,000$ in 2018 (Department of Education, 2017).
} 
Commonwealth Supported Place (CSP) assistance or HECS-HELP. These changes represent a continuous 'whittling away' of the rights of New Zealanders to access tertiary student loans, amongst other social benefits and services (Hamer, 2014).

A second pathway used by PI for migration to Australia is through family-sponsorship, which allows people already resident in Australia to financially support the migration application of family members to Australia. There are usually clear expectations between family members to provide assistance in the initial transition period (Woolford, 2009). However, while this support may have been easily provided in the past, the situation has changed, with many newly-arrived PI migrants today unable to quickly find jobs, unlike their earlier compatriots who were able to quickly and easily find jobs in the mining and manufacturing industries in the 1980s and 1990s (Vasta, 2004). According to Vasta (2004), job losses, as a result of a downturn in these industries, also resulted in some PI workers taking up casual or seasonal work in mostly nonskilled or semi-skilled employment to support themselves. Some of these earlier migrants continue to work in these non-sustainable and precarious forms of employment up to the present day.

The third type of permanent visa pathway used by PI is skilled migration. A shift in Australian Government immigration policy in the late 1990s, favoring skilled-based migration, allowed some PI families to migrate on the basis of educational qualifications, and work skills and experience. This policy aimed to provide opportunities to those with the appropriate skills and employment experiences to fill gaps in the Australian job market, whilst ensuring that these new migrants could fund their own settlement costs. A small number of PI, notably from Tonga, Fiji and Papua New Guinea, took advantage of this visa facility and migrated on their own terms and conditions (Pryke, 2014). This group, however, has also encountered challenges in terms of their settlement, not least in meeting the costs of tertiary level education, but also in adapting to high costs of living, as that found in rural and urban Australia.

\section{Literature Review}

PI move to another country in search of better schooling and labor market opportunities that will lead to positive education and employment outcomes for their families (Ravulo, 2015; Woolford, 2009). Many PI families arrive in Australia feeling confident that their children will be better assisted to achieve successful outcomes in education and employment. However, for some PI families their migration background, family socio-economic background and unaffordability to meet educational costs can negatively affect their settlement and adjustment patterns in a new country like Australia. Some PI migrants who arrived almost thirty years ago continue to face ongoing difficulties in securing long-term employment, and consequently experience ongoing socio-economic disadvantage (George \& Rodriquez, 2009). Other PI migrants, particularly those entering from New Zealand, face restrictions in terms of essential social security benefits. Due to ongoing cycles of low-level educational achievement and limited secure career-sustained employment opportunities, many PI face socio-cultural and economic challenges that consequently affect their ability to support their children's educational experiences and outcomes, particularly at the post-compulsory levels (Rose et al., 2009; Vasta, 2004).

The differences in migration history and journeys between the three cultural ethnicities - PI Polynesians, Melanesians and Micronesians, and even within the various Pacific nationalities - can cause much confusion for service providers, and PI themselves, about the kinds of services that can be accessed from community, state and national agencies. The continuous and ongoing changes to national migration rules also cause confusion for some PI, particularly for PI with New Zealand citizenship, where the regulations are quite complex and subject to regular reviews (Mares, 2016). 
In most states of Australia, students who attend primary and secondary years of schooling do not pay fees. PI learners, who hold permanent visas or those who are New Zealand citizens are regarded as domestic students and entitled to free public schooling. The situation changes, however, when learners reac $\mathrm{h} \mathrm{HE}$ and Vocational and Education Training (VET) levels of education where learners or their families are expected to meet tuition and related study costs. Citizenship and visa status become critical determinants on whether Government support can be accessed for these costs. Many Australian citizens and permanent humanitarian visa holders who are unable to meet these costs usually seek CSP and HECS-HELP to assist with meeting these costs. However, migrants with temporary (including New Zealanders) or permanent residency visas cannot access this assistance and must meet the full-fee cost which is approximately AU $\$ 2000$ for each undergraduate unit per semester (AUD $\$ 8000$ for 4 units on a full-time semester study load). For many PI learners, ineligibility to access CSP or HELP, or family unaffordability at this level, can affect their ability or motivation to participate in higher education.

Other PI families who have permanent resident visas because of family or skilled migration also face challenges with meeting the cost of HE even if one or both parents are employed. Faced with different and competing demands associated with adjusting to a new socioeconomic environment such as in urban Australia, many migrant families, including PI, may under-prioritize education costs for daily ongoing sustenance costs (George \& Rodriquez, 2009; Vasta, 2004).The irony for this group is that these families can provide the day to day physical and academic support for their children at primary and secondary levels of schooling, and encourage them to have high aspirations for further study, but they cannot afford the tuition costs for HE study, and also cannot apply for loans to pay for these costs upfront. Despite having the appropriate educational background, cultural experiences and professional networks to support their children academically and emotionally to aspire for tertiary level study, these families are financially constrained and simply cannot afford the high costs of tertiary level study.

The situation is different for learners with New Zealand citizenship, including PI, whose visa rights in Australia have consistently undergone many changes since 1973 when they were given authority to live and work in Australia. Many of these PI families, especially those reliant on low incomes and unstable employment, continue to experience ongoing difficulties in meeting their living costs, and on top of these challenges cannot also pay for their children's tuition costs. Unaffordability, therefore, seriously prohibits the success of "young people of Pacific Island heritage, who would otherwise transition to higher education (to not do so) because their residency status precludes their eligibility for essential HECS-HELP' (Chenoweth, 2014, p. 2).

However, there have been some positive changes. A recent amendment to Government legislation in January 2016 made New Zealand citizens, including PI, eligible to apply for HECS-HELP where they are considered as 'domestic' students, and eligible to receive Commonwealth Supported Places (CSP) to study at university, and also access government subsidized places in the VET sector (Spinks \& Klapdor, 2014). This new legislation, whilst helpful, is also restrictive in that the group are only eligible for HELP if they hold on to their SVC visas, which essentially keeps their visa status in Australia temporary until they successfully obtain permanent residence visas that will eventually allow for Australian citizenship application.

Whilst much of the literature on PI learner migrants' school and HE participation has focused on the cultural and social limitations of PI to adjust to Australian schooling and on low levels of aspiration or academic achievement (Ainley et al., 2000; Rose et al., 2009), less attention has focused on the effects of migration background, economic and social adjustment patterns, and 
challenges on the schooling outcomes and pathways of PI migrant learners. This article seeks to understand how migration history influences socio-economic settlement and adjustment patterns of $\mathrm{PI}$ in a new country. It explores how these factors affect the schooling pathways and outcomes of PI, focusing on two propositions: for those who have the motivation and capability to enroll in tertiary level study, their aspirations are usually constrained by the high cost of tuition fees; while those learners who have the financial means and support to enroll in higher education study are sometimes constrained by long-term poverty that affects their motivation to study at the higher or tertiary education levels.

\section{Study methods}

This study follows the migration history, family background, settlement patterns, and school trajectories of a group of second-generation PI learners in Melbourne's western region in order to illustrate their differing effects on their educational pathways. The case stories of five PI learners - Ama, Sela, Timo, Via and Lisi, selected based on the marked differences in migration journey, family socio-economic background, and school pathways and outcomes - are outlined to explain how these factors impacted on the educational trajectories of the individual learners.

Data was collected primarily through conducting yearly semi-structured interviews with each participant over four years from 2012 to 2015 . Two interviews each were also conducted with family members of each participant, and one interview was held with a staff member from the participant's school over the same period. The five participants all lived and attended school in Melbourne's western region. The small size of the cohort dictated a longitudinal case study approach to data collection to obtain detailed and in-depth information over a prolonged period (Yin, 2012). A case study inquiry approach was used to analyze and interpret data, recognizing its potential for in-depth exploration of meaning in the ideas, words and actions of all participants, while also focusing on transformations occurring over time (Burns, 2000; Merriam, 2009). Consistent with Yin (2012) and Merriam (2009), case study research promotes inductive reasoning whereby the majority of ideas, concepts and abstractions about the topic of study emerge and evolve from an examination of the data. Case study research lends itself to data analysis that is essentially interpretive, with the theorizing and reporting of research outcomes predominantly based on the researcher's interpretation of meanings gleaned from the ideas, words and actions of the research informants.

All participants self-identified as having a PI ancestry and all were second-generation migrants to Australia. All the families had arrived in Australia between 1995 and 2005. One family from Melanesia had migrated directly from their country using the skilled migration pathway. The families of the other four participants, all Polynesians, had step-migrated through New Zealand utilizing their citizenship or visa rights as New Zealanders to settle permanently in Australia. While one participant held a permanent resident visa (Ama), another was an Australian citizen (Sela), two (Via and Lisi) held Special Category Visas (SCV), and one (Timo) held a non-SC visa. All five participants were enrolled in post-compulsory secondary school studies in either the Victorian Certificate of Education (VCE) or the Victorian Certificate of Applied Learning (VCAL). The VCE pathway is often selected by students hoping to transition to university, while the VCAL pathway provides a common route to Technical and Further Education (TAFE) study. By the end of the study period, one of the participants was enrolled in a degree course at university, three were at TAFE, and one was employed. The next section outlines the school trajectories of the five participants to understand the different ways that migration background, socioeconomic status and financial unaffordability affected their post-school pathways.

\section{Case studies}

Ama, a Melanesian female, arrived in Australia in 2005, where her mother, a nurse with Australian qualifications, had successfully applied for permanent residence visas for her family 
under the skilled migration pathway. Ama's mother had a full-time professional job. Ama was in Year 12, the final year of VCE in 2012 and planned to study medicine at university. Her family provided the necessary physical and academic resources to support her studies and Ama was confident of achieving her goal. However, at the end of VCE, Ama's Australian Tertiary Admission Rank (ATAR) result was insufficient to enrol into a degree course in medicine. Instead, she accepted an offer to study a general science degree.

As a permanent resident, Ama was ineligible for CSP to assist with the tuition costs at university (approximately AUD $\$ 8,000$ per semester for a four unit full time load), and her parents could not afford it, let alone pay the full cost upfront. Ama's parents' pre-occupation with providing their daughter the material and emotional support to aspire for tertiary education had not been backed up with putting aside funds for her university tuition costs. Ama risked losing her university place even before enrolling, but fortunately for her, the enrolling university agreed to waive costs until a later date so that Ama could apply for Australian citizenship, which would give her eligibility for CSP assistance. Whilst family financial unaffordability threatened to block her tertiary education pathway, Ama was able to overcome her barrier by receiving special assistance from her university. Her parents also learned that, had they applied for citizenship for Ama prior to her applying and enrolling for a university place, they would have avoided a tense situation for the family.

In 2012, Sela, a Samoan female, was in Year 11 VCE and hoping to study a nursing degree at university in two years. As a citizen, Sela could access CSP and a HELP loan if she decided to pursue university or TAFE studies. Sela's parents, who had moved to Australia from New Zealand in 1995, could reside permanently in Australia where her father worked as an unskilled laborer, while her mother worked as a postal clerk. The family gained citizenship status in Australia after the Australian Social Security Act amendment of February 2001 came into effect when New Zealand citizens arriving after that date became ineligible to identify as permanent residents, with restricted access to tertiary student loans, public housing and disability services (Hamer, 2014).

Despite having access to CSP or HELP for her university costs, Sela's challenging family and home circumstances affected her ability to stay focused on her school work. Midway through Year 11 VCE, Sela's father became ill and stopped work which meant her mother, a night shift clerk, became the sole income earner. The family moved housing a few times due to financial hardship. Her mother's continued absence from home in the evenings also meant that she could not supervise or support Sela with her school work. Additionally, Sela took on added household responsibilities at home which affected her school attendance and performance.

Although her parents supported Sela's dream to study at university, they could not provide the necessary material or emotional support to help sustain Sela's schooling goal. Changes affecting family finances within the home affected Sela's interest and motivation, which eventually affected her school performance and eventual withdrawal from school. Sela later enrolled in a TAFE certificate course in order to secure a pathway back to university, while her parents were initially unhappy with this option, having hoped for Sela to transition directly to university after secondary school.

Timo, a Tuvaluan male whose parents live in New Zealand, arrived in Melbourne in 2010 to live with his uncle's family. Timo was able to live in Australia and attend free public schooling under the SCV facility. He attended Year 12 VCE at the local school with his uncle's son who was the same age. Both boys expected to complete VCE successfully that year. Timo's uncle worked on night shifts which prevented him from being present at home in the evenings to supervise and support the boys with their school work, but he encouraged them to work hard and go to university. Timo and his cousin were often left to complete homework without 
supervision. Outside of school, Timo spent most of his time with his cousins at the gym, shops or playing rugby.

Timo wanted to study paramedic nursing at university after VCE and did achieve the grades to pursue the course. However, he decided to find a job rather than pursue university study saying that "getting a job is the best option for me and my family as I cannot access CSP or HECS-HELP for university tuition costs due to my New Zealand citizenship" (Timo interview, January 2011). As a New Zealand citizen who had been in Australia less than ten years, Timo's SCV status restricted his access to CSP assistance or HECS-HELP despite him achieving the necessary ATAR score to study nursing. Timo's decision to waive university studies despite being eligible for 'domestic student level' fees as a SVC holder was helped by his view that "I do not want to place extra financial burden on my family to pay for fees and I can assist my family better by earning income to help support them".

Via lives with her grandmother in a house opposite her parent's home. Via's parents moved to New Zealand from Tonga before migrating to Australia in 1998 when Via was a baby. Her father works at a fruit and vegetable grocery shop, although he had plumbing qualifications and worked as a plumber in his home country. Via's father said he found it difficult to get a plumbing job in Melbourne due to a vision impairment, which led him to do whatever job required to support his large family. His eldest daughter also worked at the same grocery shop.

Via attended school close to home, saying "I feel supported at school. Teachers are goodthey expect us to ask them for help if we do not know how to do the homework" (Via, Interview 1, June 2012). In Year 10, Via decided she wanted to become a teacher and joined the VCE class. She reported having no major challenges at school and was well connected to her teachers, friends and family, especially her grandmother, with whom she lived and who encouraged her to do well at school. After VCE, Via was accepted into a Diploma in Arts course at the nearby university. Her family were disappointed that she was unable to transition directly to university from secondary school, but they also supported her decision, knowing that she and her teachers knew best her options.

Lisi self-identifies as a Samoan and is the eldest in a family of four. He was attending Year 10 when he joined the study in 2012. He started a TAFE course two years later. From Year 10, Lisi knew he wanted to get a trade qualification in plumbing or carpentry. Lisi was engaged at school saying that he enjoyed all his subjects except Science, and that he found his teachers friendly and the school a safe and comfortable place. He had many friends and one of his highlights in Year 10 was performing as a drummer in the school music concert.

In Year 11, Lisi did VCE studies but switched to VCAL in Year 12 and started an apprenticeship at TAFE in 2015. Lisi's goal of becoming a tradesperson aligned with that of his parents who allowed him to choose his own career. The school was also supportive of this pathway for Lisi, and for him there were no real or apparent barriers from family or school to distract his goal of becoming a tradesperson.

Lisi's family had migrated to Melbourne in 2002 from New Zealand where they had lived for 10 years after their original move from Samoa. Lisi's parents both worked full-time; his mother, an accountant with a Diploma in Business qualification, had recently graduated from the nearby university. Lisi's mother had chosen Lisi's school due to its good reputation for the support and resources provided to learners. 
Table 1: A demographic summary of the five cases

\begin{tabular}{|l|l|l|l|l|l|}
\hline Name & Ancestry & Visa type & $\begin{array}{l}\text { Highest } \\
\text { qualification in } \\
\text { household }\end{array}$ & $\begin{array}{l}\text { Parental } \\
\text { employment } \\
\text { type }\end{array}$ & $\begin{array}{l}\text { Post- } \\
\text { school } \\
\text { pathway }\end{array}$ \\
\hline Ama & $\begin{array}{l}\text { Papua } \\
\text { New } \\
\text { Guinea }\end{array}$ & $\begin{array}{l}\text { Permanent } \\
\text { resident }\end{array}$ & Post graduate & Professional & $\begin{array}{l}\text { University } \\
\text { Degree }\end{array}$ \\
\hline Sela & Samoan & Citizen & $\begin{array}{l}\text { TAFE } \\
\text { Certificate }\end{array}$ & Clerk/Secretarial & $\begin{array}{l}\text { TAFE } \\
\text { Certificate }\end{array}$ \\
\hline Timo & Tuvaluan & Non SCV & $\begin{array}{l}\text { High school } \\
\text { Certificate }\end{array}$ & $\begin{array}{l}\text { Unskilled/semi- } \\
\text { skilled }\end{array}$ & $\begin{array}{l}\text { Direct } \\
\text { employment }\end{array}$ \\
\hline Via & Tongan & Non-SCV & $\begin{array}{l}\text { Trade } \\
\text { Certificate }\end{array}$ & $\begin{array}{l}\text { Unskilled/semi- } \\
\text { skilled }\end{array}$ & $\begin{array}{l}\text { TAFE } \\
\text { Diploma }\end{array}$ \\
\hline Lisi & Samoan & SCV & TAFE Diploma & Professional & $\begin{array}{l}\text { TAFE } \\
\text { Certificate }\end{array}$ \\
\hline
\end{tabular}

\section{Findings and discussion}

The case studies of these five PI learners demonstrate the different ways that migration history, family socio-economic background and financial affordability affect the educational experiences and pathways of these group of learner migrants in Australia. These barriers are most noticeable and impactful at the post-compulsory secondary schooling stage, a time when a family's financial contributions to schooling are expected to increase, coinciding with a period when learners gain more independence and feel more empowered about the choices made about their future (Bourne, 2008).

\section{Family background and Income level}

Financial incapability to meet tuition costs, and to meet these costs upfront, were especially challenging factors to learners like Ama and Timo, both of whom had the academic capacity to study at university but lacked the financial means to pay for the fees. Whilst Ama's parents had succeeded in raising their daughter's aspirations and academic requirements for university study, they lacked the financial means to cover her university costs. They also had insufficient information about the opportunities open or available to prepare themselves for Ama's transition to university study. Without appropriate advice from Ama's school and intervention from her enrolling university, Ama may not have enrolled in a degree course at university.

Ama's experience supports the view that unaffordability adds an extra layer of challenge to tertiary education access (Chenoweth, 2014; Kearney \& Glen, 2017) for migrant families, who may have insufficient information and knowledge about university costs and ways to access these funds. Proper communication and information flow between the family and the school could have prevented this misunderstanding.

Despite the apparent financial challenges, many families in this study consistently downplayed the impact of cost on their children's education, re-iterating a commitment to provide the financial means to support their children's school goals, whatever the cost. Yet, the data consistently pointed to family financial stress as a major factor in the decisions concerning higher education study, with some learners' obviously under-prioritizing personal learning goals for broader collective financial gains for their families.

Sela, Via and Timo's stories illustrate the importance of family income on shaping learner's 
educational choices and pathways. In these homes, frequent and continuous parental absences contributed to a weak supportive framework for these learners, as did low supervision and inadequate monitoring of homework. Sela's home responsibilities contributed somewhat to her loss of focus on her studies, "my caring responsibilities have increased due to my father's illness which means that I sometimes cannot complete my homework" (Sela, Interview 2, August 2012). In contrast, Timo had fewer responsibilities at home and potentially more time for school work, but due to low supervision, did not always feel pressure to put this time to school work - "I like taking part in class discussion but I do not like doing homework" (Timo, Interview 1, April 2012). In these cases, employment demands and low parental income combined with poor supervision at home to inflict reduced capabilities for providing the necessary material and academic supports needed by the learners. Additionally, the ongoing financial stresses in these homes contributed to lowering levels of motivation to study at $\mathrm{HE}$ levels, particularly if there is a view that long-term studies could bring additional financial burdens on already struggling families. This realization alone influenced Timo's decision to select a direct employment pathway rather than continue his education.

Some parents in the study were consistently conflicted about whether to apply for Australian citizenship to enable their children to access Commonwealth support through CSP or HELP, especially when they reached the stage of enrolling in either a TAFE or university course. For a permanent resident like Ama, this was a straight forward process of putting in an application for citizenship. But for others like Timo, the process of acquiring citizenship was more complex, considering that he held an SVC visa, disallowing citizenship application without first getting permanent residence status. But acquiring a permanent resident visa is a bigger hurdle for many families who cannot meet the necessary conditions to be eligible to apply. These conditions include having their skills contained on the immigration skills list or being eligible for employer sponsorship, which many New Zealand PI may not easily satisfy due to the nature of their migration entry. There are also age restrictions (must be under 45 years of age) and applicants must also have earned well for five successive years to save and afford the permanent residency application costs $^{3}$. The challenge of cost for acquiring permanent residence status alone can be a deterring factor for families wishing to apply for citizenship for the purpose of accessing CSP or HECS-HELP.

\section{Cultural commitments}

Family connectedness is viewed by PI as a central purpose for life and living, where obligation and reciprocity are important virtues (Fairbairn-Dunlop, 2010; Thaman, 2008). These virtues, however, may not always have positive implications on the ways that young PI perceive their schooling or career choices. Sometimes educational goals may be subjugated for family priorities; a young PI might consider direct employment as a more suitable pathway option compared to further education. Timo's deliberate choice of a direct employment pathway is a case in point. Timo knew that his choice conflicted with his parents' wishes, but he also considered his decision as the best option for everyone concerned. Whilst these cultural obligations were highly valued as important strategies for strengthening family and community connectedness and upholding PI values of obligation and reciprocity amongst family members locally (Thaman, 2008), this study found they had minimal effect on learners' schooling experiences or pathways when compared to the more serious impact of financial unaffordability.

Conversely, connectedness with and support for community diaspora was an important source of strength for some learners and families who benefitted from the sharing of important

\footnotetext{
3 The cost of a permanent resident visa for a family is $\$ 3,600$ for the primary applicant, $\$ 1800$ for the partner, $\$ 1800$ for a dependent child aged 18 to 24 years and $\$ 900$ for dependents aged under 18 years (www.border.gov.au)
} 
information and knowledge (Thaman, 2008) about education, employment, and welfare opportunities and services available within the communities. Within the various communities also, learners were able to identify with successful education, sports and arts role models, as well as teachers and family members. The past successes of parents and older siblings in education and employment were important motivating factors for participants, including Ama, Via and Lisi, to do well at school. In Lisi's case, there was less pressure to select a direct employment pathway, due to both his parents having full-time employment and his mother engaged in a professional job with a stable income.

Whilst the various cultural and island PI communities appeared to have strong internal connectedness within themselves, the relationships to networks and services within the broader community appeared to be weak, with obvious barriers to effective bonding and bridging with wider community services and networks, which are necessary for accessing important information on educational scholarships, career options and university costs. Moreover, a tendency to restrict support sources to within family and/or specific PI diasporic communities also constrained access to important relevant information or financial support due to a lack of confidence to seek assistance. In these instances, PI could be seen to contribute inadvertently towards their own isolation from the broader community.

\section{Complex and confusing expectations}

The differences in the ways that benefits and services are offered and granted to various cohorts of visa holders was a constant cause of confusion for many learners and their families. Due to the differences in entitlement to services and benefits, some PI families' reliance on the supportive frameworks of family and community to provide information on many complex issues related to their settlement needs were sometimes compromised. In education terms, this included the assumption by parents that tertiary education, as for primary and secondary education, would not attract fees from non-citizen residents. This kind of misinformation, as evidenced by Ama's family, showed that PI require information about the real costs of $\mathrm{HE}$ and the kinds of support available (or not) to them based on their migration background. Additionally, school staff, especially career guidance officers, sometimes lacked accurate information about differences in visa status of PI learners and the cost implications of these differences for study at TAFE or university levels.

\section{Limited experiences with education}

Low experiences of education also affected some families' abilities to engage effectively and confidently with a school's academic requirements, such as providing time, support and advice to their children. This was especially true in the cases of Sela, Via and Timo whose parents viewed the school as the appropriate domain and authority to provide such advice and support (Fairbairn-Dunlop, 2010). Limited incomes within these family homes also meant there was little external assistance or supervision that could be provided at home while they attended to their jobs to bring in income for the family's basic sustenance needs.

\section{Conclusion}

For many $\mathrm{PI}$, their migration background, visa status and family socio-economic situation directly affects their ability to access HE pathways. High cost of HE and VET fees, long-term and ongoing dependency on temporary forms of employment, and low income affects in different ways these learners' individual pathways to TAFE or university. Long-term general poverty consistently impacted on some leaners' aspirations for further study, which consequently affected their engagement and achievement at school. 
New arrival PI migrants who had access to long-term secure employment, with an ability to nurture positive aspirations and provide academic, economic and social support to their children to achieve at school, were hindered by the high cost of university tuition and the need to pay these costs upfront. For those who had the academic capability to enter university, pressures about the financial burdens likely to be placed on families from further HE or VET study caused some learners to under-prioritize higher education for other pressing priorities at home.

\section{Lessons for future}

More detailed and accurate information on scholarship or sponsorship options for PI learners and families who are ineligible for Government assistance is needed. School careers personnel must seek better understanding of learner's visa background and entitlements, levels of in-home support structures, and family socio-economic backgrounds to develop realistic and appropriate post-school pathways for those who may be disengaging.

Early detection of learners who show potential and ability at school is needed. For those with eligibility for Government assistance, stronger social and academic scaffolds at the school and home spaces can greatly support these learners to follow appropriate and realistic pathways.

Tertiary institutions can also assist by applying more flexible strategies for the payment of tuition fees to those who cannot afford it, including offering targeted scholarships to learners who need more support, such as PI learners or those from other equity groups.

At the community level, more collaboration between key educational stakeholders and the PI community is needed to share information about visa status, entitlements and benefits, and the impacts on schooling outcomes, transitions and overall social adjustment and inclusion of PI migrants into broader Australian society. 


\section{References}

Ainley, J., Frigo, T., Marks, G.N., McCormack, S., McMillan, J.M., Meiers, M. \& Zammit, S.A. (2000). The Measurement of Languages Background, Culture and Ethnicity for the Reporting of Nationally Comparable Outcomes of Schooling, Australia: Australian Council for Education Research (ACER).

Bedford, R., Ho, E. \& Hugo, G. (2003). 'Trans-Tasman migration in context: Recent flows of News Zealanders revisited', People and Place, 11(4), 53-62.

Bourdieu, P. (1997). 'The forms of capital', in A.H Halsey, H. Lauder. P. Brown \& A. Stuart (eds.) (1997) Education - Culture, Economy and Society, OUP Higher Education

Bourne, D. (2008). 'Young People, identity and living in a global society', Policy and Practice A Development Education Review, 7, 48 -6.

Burns, R. B. (2000). Introduction to research methods (4th ed.). Australia: Longman Publishing.

Chenoweth, L. (2014). 'Pacific Islanders and education: is Australia an 'unlucky country'?', The Conversation. Retrieved from https://theconversation.com/pacific-islanders-andeducation-is-australia-an-unlucky-country-21920 (accessed Feb 10 ${ }^{\text {th }}$, 2014).

Connell, R. W. (2003). 'Working-class families and the new secondary education', Australian Journal of Education, 47(2), 35-50.

Department of Education. (2017). The Higher Education Reform Package, Canberra, Australia.

Fairbairn-Dunlop, P. (2010) 'He's Won, but he's lost it', Alternative: An international Journal of Indigenous Peoples, 6(2), 143-154.

George, J. R \& Rodriquez, L. (2009). 'Hybrid youth identity in the Maori/Pacific Island diaspora in Australia: A study of young urban Polynesian men in Sydney', New Zealand Sociology, 24(1), 1-24.

Hamer, P. (2014). 'Unsophisticated and unsuited': Australian barriers to Pacific Islander immigration from New Zealand', Political Sciences, 66(93), 93- 118.

Kearney, J. (2012). 'Unlucky in a lucky country: A commentary on policies and practices that restrict access to higher education', Journal of Social Inclusion, 3(1), 130 - 134.

Kearney, J., \& Glen, M (2017). 'The effects of citizenship and ethnicity on the education pathways of Pacific youth in Australia', Education, Citizenship and Social Justice, 12(3), 277-289.

Mares, P. (2016). 'Unintended consequences of temporary migration in Australia', in Unintended Consequences : The impact of Migration Law and Policy, ANU Press, Australian National University, Canberra, pp 81-122.

Marginson, S. (1999). 'Equity, status and freedom: A note on Higher Education', Cambridge Journal of Education, 41(1), 23 - 36.

Merriam, S. B. (2009). Qualitative Research and case study applications in Education. San Francisco, USA: Jossey Bass.

Paulsen, I. (2016). Negotiating partnerships; rethinking collaborative partnerships to improve the educational outcomes of Pacific Islander young people in Melbourne's Western region. Unpublished PhD thesis, Victoria University, Melbourne.

Pryke, J. (2014). 'Pacific Islanders in Australia: Where are the Melanesians?', in DevPolicy Blog, Development Policy Centre, Canberra.

Ravulo, J. (2015). Pacific communities in Australia, Report, University of Western Sydney, NSW, Australia.

Rose, S., Moore, C. \& Quanchi, M. (2009). 'A national strategy for the study of the Pacific', Australian Association for the Advancement of Pacific Studies (AAAPS), Brisbane.

Samu, T. W. (2007). 'Revisiting the 'Pasifika way' for a new school of Pasifika Education', Center for Pacific Islands Studies, University of Hawaii, Occasional Paper 43, 137 150. 
Singh, P. \& Sinclair, M. (2000). 'Diversity, disadvantage and differential outcomes: An analysis of Samoan students' narratives of schooling', Asia-Pacific Journal of Teacher Education, 29(1), $73-92$.

Spinks, H., \& Klapdor, M. (2014) New Zealanders in Australia: A quick guide. Retrieved from: http://www.aph.gov.au/About_Parliament/Parliamentary_Departments/Parliamentary Library/pubs/rp/rp1314/QG/NZinAust

Thaman, K (2008). 'Nurturing relationships and honouring relationships: A Pacific Perspective', International Review of Education, 54(3-4), 459-473.

Vasta, E. (2004). 'Community, the state and the deserving citizen: Pacific Islanders in Australia', Journal of Ethnic and Migration Studies, 30(1), 195-213.

Woolford, G. (2009). Social protection for Migrants from the Pacific Islands in Australia and New Zealand: World Bank, Human Development Network.

Yin, R. K. (2012). Applications of case study research (3rd ed.). Thousand Oaks, California: SAGE.

\section{Biographical Notes}

Irene Paulsen works for Auckland Uniservices Limited (AUL), University of Auckland as Programme Manager for the Leaders and Education Authority Programme (LEAP). She is an academic and mentor who is interested in researching about Pacific Islander learners' engagement and achievement in education with a particular focus on post-secondary school transitions, migration and settlement patterns, and their impact on educational pathways.

\section{Appendices}

\section{Appendix 1}

\section{Interview 1 (Started in Feb 2012)}

\section{General}

- When others ask you where you are from, what do you say? Why do you self -identify as such?

- What are your hopes and fears, concerns as a young PI growing up in Melbourne?

- What are some opportunities/ challenges that you have as an islander? What do you think you miss out on due to your culture?

- How are young PI viewed by other people in the community/school?

\section{Family}

- What are your goals and how can your family help you achieve these?

- Is there anyone at home that has been particularly helpful to you? What did they do? Why? How does this attention affect your attitudes to life, schooling or subjects/wellbeing etc?

- How can your family help you meet your learning aspirations/needs/challenges better? Give some examples of these events and explain why or how this action impacted on you.

- How can the home be a more engaging/interesting/welcoming place for you? Do you find anything at home particularly difficult or challenging? What are these?

\section{Schooling}

- What has been your experience of schooling so far? Identify major highlights and challenges. At what stage of schooling did you experience these lowlights or highlights? What or who played an important part in the ways you felt about this event? 
- What are your goals and how can the school help you achieve these?

- Is there anyone at school that has been particularly helpful to you? What did they do? Why? How does this attention affect your attitudes to schooling or subjects/wellbeing etc?

- How can school/teachers help you meet your learning aspirations/needs/challenges better? Give some examples of these events and explain why or how this action impacted on you.

- How can the school be a more engaging/interesting/welcoming place for you? Do you find anything at school particularly difficult or challenging? What are these?

- Who do you go to for help/advice about your homework/ school needs/ career choices? How often do you ask for or receive this information?

- What do you/your friends/parents think about VCE studies/TAFE/university/employment?

\section{Outside School}

- How /where do you spend your time outside of school? How do these activities/relationships impact on your studies?

- What do you see yourself doing in 2 years' time? What would your parents like you to do when you are older?

- What does a good life mean to you?

- How do your parents speak to you about how you can achieve a good life?

- Who is your role model? What about that person makes them a role model to you?

- Who or what has made a difference to the way you think about education?

- How did this come about ie is it ongoing or one -off?

- What happened? How did you feel?

\section{Interview 2 (Started July 2012)}

\section{Introduction}

How have you been in the last six months?

Is there an event that occurred at home that stood out for you in the last six months?

How did you feel before or after it? How could it be changed or improved for the future?

Is there an incident in school that stood out for you in the last six months? Why was it important for you? How did you feel before or after the incident took place? How could you have changed the situation if it occurred again in the future?

Who has been the most important person at school for you in the last six months? Why and how?

What are your expectations from school, from teachers? Are these being fulfilled? Do you think school is helping you achieve your goals?

\section{School staff}

How do teachers normally treat you? Is this the same kind of treatment they would give to other islanders/ migrants/ groups? What qualities do you like in a teacher? Do teachers interact with your parents at any time?

What other staff in the school do you work with? How do you find their attitudes towards you? Are they kind, helpful and friendly?

What do you think about other students at the school?

\section{Home/family}

How do you identify yourself with other people eg friends, teachers, school, community members?

How do others in the community view PI? Why? How do PI want to be viewed/ Would you identify yourself as PI or Tongan or Samoan etc?

How would you rate the support that family members have provided to you in general? What do you do for money eg pocket money, educational resources ie books, stationery, camps, uniforms? Do you pay for these yourself or does a parent buy these for you?

Is there anyone else within your family that provides you with support? What sort of support would you like your mum/dad/parents/other family members to give you more of?

\section{Connection to home/country}

How do you keep in touch with family members? 
Do you speak a native $X$ dialect? How often do you speak it?

Do you keep in touch with cousins back at home?

\section{Friends}

Who would you consider to be a close friend? What is it about your friend that you most like?

What sort of qualities do you look for in a friend?

How important is your friend in your schooling or personal life?

Is there an event that occurred in the last six months with a close friend that you remember?

What happened? How did you feel before or after the event? If given the chance how would you change or improve your response in future?

\section{Post school options}

Last interview, you said you liked school because.... Is this still the same? What are your feelings towards your studies in the last six months? Have you changed your views about VCE/VCAL, your pathways etc. What do you think influenced these changes or what has helped reinforce your goals from six months ago? Do you think these may change in the next six months, one year or two years?

\section{Careers Advice}

Last time, you said you would like to do $X$ when you leave school. Are you still interested in doing $X$ ? If yes, what have you done to further this interest in the last six months? What have you done so far to help you achieve this goal./ Does school help you achieve this goal? Have parents helped? How?

If you have changed your interest, why do you think it changed? What or who influenced the change? Why do you think it changed?

Who would you take advice from about your career or future job? Teacher or friends or dad or mum?

\section{Interview 3 (started July 2013)}

\section{Significant events in the last six months}

What are the most important things that have happened to you in the last six months?

What important event has occurred at home in the last six months?

What important events have occurred at school in the last six months?

\section{Home support}

How important are the following to you? To your family? To your friends?

- Family relationships

- Friends

- Schooling

- Church

- Money

- Island community

In what ways is your family important to you?

- Providing food, accommodation

- Physical and Mental support

- Helping with homework

- Helping with money

How can they improve their support?

Rate (from 1 to 5 ) the levels of support received at home for the following:

- Assistance with homework from mum

- Assistance with homework from dad

- Assistance for homework from a family member (brother or sister)

- Pocket money

- Emotional support - Wellbeing, feeling loved, happy, confident

\section{Schooling Support}

What things that occur at school are you happy about?

Which two people in school do you relate well with? Why? 
What are the things that bother you at your school?

What are some things at school that you wish you knew more about? What subjects do you want more help with?

What kinds of help do you get from school? Rate the level of assistance you get from school. Transitions

- How can you describe your progress in schooling /education so far?

- Have there been any shifts in terms of your aspirations/ attitudes towards your education or future career since your last interview? Give examples of these shifts in thinking and explain how they affect your journey as a student completing post -compulsory education?

- What support /assistance /challenges (whether at home, school or other) have contributed to these shifts in thinking/attitude?

- Can you list some moments in your educational journey that have contributed to your motivation for continuing/discontinuing your education after post compulsory schooling?

- Can you share some thoughts about what you see yourself doing in three to five years' time?

- How will you go about trying to achieve this goal?

\section{Interview 4 (Started Feb, 2014)}

Think about two of your best childhood friends from Primary school. What are they doing now? How similar or different from you have their experiences been? Do you think these chosen pathways have been successful? Why do you think their pathways are different or similar to yours? What influences have impacted on their outcomes?

Two years ago, you said you wanted to do ..... What has become of those plans? Why have they changed or stayed the same?? Has anything or anyone been responsible for these changes? So far, what has been the turning point for you in your educational journey?

So there have been some changes in your schooling journey in the past two years. How do you feel about making such changes? Have you had some influence over these changes? What are the factors in life that influence these changes/choices/decisions etc. Is it easy or difficult to make these changes and is there any pressure to stick to these goals?

To what extent does your family impact your educational choices and decisions? There are some people in the school community who say that parents do not provide much support to students. What do you say to these views?

What constitutes success for you?

What supports can family members realistically provide? Are you satisfied with the help that they have provided? How would you advise parents on ways to better support their children at school?

How many hours would you spend on home work after school? How else do you spend your time after school? In a typical weekend, how much time would you spend on the following things -homework/ study, personal, family and house chores.

\begin{tabular}{|l|l|l|}
\hline Activity & Tasks & Time spent \\
\hline Study & $\begin{array}{l}\text { studying for a test, reading a } \\
\text { textbook, writing an essay, } \\
\text { reflecting on class notes }\end{array}$ & \\
\hline Family chores & $\begin{array}{l}\text { Washing, cleaning, cooking } \\
\text { babysitting, watching other } \\
\text { children }\end{array}$ & \\
\hline Personal time & $\begin{array}{l}\text { Visiting or chatting with friends, } \\
\text { movies, shopping, reading, } \\
\text { facebook, watching TV }\end{array}$ & \\
\hline Community & Church, youth group, sports & \\
\hline
\end{tabular}




\begin{tabular}{|l|l|}
\hline Learning Style & Tick any that apply \\
& $\begin{array}{l}\text { One on one } \\
\text { sitting down with me and showing me how to do it } \\
\text { reading it myself and taking time to understand } \\
\text { listening to a teacher explain it }\end{array}$ \\
\hline Learning space & $\begin{array}{l}\text { Formal setting eg in a classroom, Library } \\
\text { Non-formal setting eg sports field } \\
\text { Informal - youth centre, camp }\end{array}$ \\
\hline Career & $\begin{array}{l}\text { VCE or VCAL } \\
\text { TAFE or University }\end{array}$ \\
\hline Complete these prompts & $\begin{array}{l}\text { I believe my learning would improve } \\
\text { I prefer to learn } \\
\text { I like learning } \\
\text { I would like a job that } \\
\text { I would do anything to }\end{array}$ \\
\hline
\end{tabular}

What do you hope to do in the next few years? How has being involved in this research impacted on your schooling? Has it improved anything ie personal development, study skills, attitudes to school, parental resourcing?

\section{Appendix 2}

\section{Interview 1 - Family members}

The researcher used semi-structured interview questions to gather data and focus the interview sessions such as:

- What are your views about education and schooling? Identify high and low moments you experienced during your own educational journey. How have these impacted on your life/career so far?

- Are you generally satisfied or happy about where you have reached in terms of your own education? If you were able to study further, what sort of studies would you like to do? Why?

- Have other members of your family been to University or TAFE? What has been their experience of these institutions?

- What are your hopes and goals for your child in terms of education, work, career and life in general? Are these goals similar or different for each child? Do you think these goals are on their way to being achieved?

- How similar or different are your children's educational goals or attitudes to schooling compared to your own goals/attitudes to schooling? What might be the reasons for differences and similarities?

- How often do you speak with your children about these goals? How can you /the school/others help your child meet their learning aspirations/needs/challenges better?

- How do you support your child's studies at home? How can the family support him/her better?

- What can you say about the school's support for your child? Are you satisfied with it? How can schools/teachers work with you to support your child/children or other learners of similar background? Are you able to voice your concerns for your child if necessary?

- What do you/your child and your family members think about VCE studies/TAFE/University education/employment? Why do you have these views? Do you have conversations with your child about their post-school options?

- How well do you understand the education system? Does the school provide information to you about TAFE or university or employment options for your child? If not, where do you get this advice?

- Do you speak with your child about what subjects they should take? How much advice can you provide to your children about furthering their education? 
- Who do you seek information from about matters such as homework, school help, subject options, career options that your child might need? What sort of advice about education do you find that you are not aware of or do not have enough of?

- How much assistance do you get from the school?

- How would you describe your own influences over your child's educational choices or decisions? How about that of other members of your family?

What do you see your child doing in 2 years' time ie in terms of schooling, training or employment?

\section{Interview 2: Family members (started 17 Feb 2014)}

The second interview session with the family unit occurred in the third year of data collection and was used as a follow-up to the first one.

\section{Demographics}

Where did you do your secondary education? What is your highest qualification?

When did you come to Australia? Why did you choose to live in the suburb you are in now? Have you always lived in this area? Why did you move? Was it a difficult or easy choice to move to Australia?

\section{Schooling}

What are your thoughts about the Australian education system? Is it supportive of PI students? Do you know much about what the students learn and how it is learned in the classroom? Is it the same as how you viewed it when you first came to Australia?

What have been some of the difficult choices/decisions you made concerning your child's education?

What are some of your joys about your children's education in Australia?

What are your greatest concerns about your child studying in Australia?

What constitutes success for you in terms of your child's education and career?

How do you think your own education background and experience has affected your child's experiences of schooling?

Think about when your child was in Year 7, 8 and 9 and now in Years 10,11 and 12. Have there been any differences?

Some teachers tell us that for PI young people, their attitudes to schooling change when they get to senior years. These changes are in the areas of homework completion, time spent on homework, support for extra-curricular studies eg tutoring, time for church and other community events? Do you think these things affect children's schooling? How?

What are your views about church and schooling? Do these go together? In what way? How much of your children's time would be spent on church or community tasks?

What do you think about non-traditional subjects such as music, Art etc? Do you think it is good to follow a sports or music career from an early stage ie secondary schooling? Are you aware of the supports provided for young people in your LG area?

- Library

- Homework groups

- After-school care

- Parents and children support groups at LG

Would you attend these or ask your child to attend these. If not, why not? How useful are these to your family?

Are there partnerships we have not spoken about that you know can help you with your children's schooling? Do you sometimes feel angry or overwhelmed in thinking about your child's education?

Do you see school as an important partner in your child's education? Why? Who are other people/groups or institutions you think should be partners in the education of your child? What other things can schools do to help you help your child better?

\section{The last two years}


- Tell me about your family /home circumstances. Has anything changed? What have been some important events and activities since our last meeting?

- What are your views/attitudes about education and schooling since your last interview? Have any of these changed? Why? Has any significant family event affected your attitudes about your child's education? Has this been triggered by your child's experience/activities? What have been your response/ reaction to this change?

- How can you describe your child's progress in education so far? Are you satisfied with their experiences? Who or what has helped them achieve / not achieve this progress?

- Have there been any shifts in terms of your aspirations/ attitudes towards your child's education since your last interview? Give examples of these shifts in thinking and explain if and how they affect your views about your child's journey as a student completing compulsory schooling or post -compulsory education? How have you responded to the changes in your child's learning needs?

- What support /assistance /challenges (whether at home, school or other) have contributed to these shifts in thinking/attitudes?

- Can you list some critical moments in the last two years that have occurred which may have affected your views about the education of your child? How have these shaped your views about supporting/ not supporting your child's education up to and after post-compulsory schooling?

- What changes/adjustments need to happen in the home/ school/community to help your child achieve his/her goals in education, especially at post compulsory levels of schooling?

- Can you share some thoughts about what you see your son/daughter doing in three to five years' time?

- How will you go about trying to help your child achieve these goals?

- Do you think schools are supportive and are there for you when you need that support? How can they support you better? If your child's school asked you to provide some suggestions about how to support your child better at school, what would you say?

- What can schools/universities do to help your child achieve his/her goals?

\section{Finance}

How much of a factor is finance in terms of the decisions you make about your child's education?

\section{Homework time}

How important to you is it that your child finishes their homework? What strategies are in place at home to ensure that your child finishes homework? What support or help can you give? Have you considered getting a tutor to help?

\section{Extra- Curricular activities}

What extra things do you do to support your children's education? Have you considered tutoring assistance or homework clubs?

\section{Sports, Arts and Music}

$\mathrm{Pl}$ are known for their love of sports? How much sports do your children play? Would you encourage your children to follow a sports career if they showed some encouragement and interest in it? How would you go about furthering their interest in this area?

\section{Community}

Have you made any changes to your living arrangements since our last meeting? Did these changes have anything to do with your child's education?

\section{School}

What can your child's school do better? Do you feel you have the skills to be able to communicate with the school about your child schooling?

Learning Styles and Spaces

Where do you think you learn best?

\section{Careers}

VCE or VCAL/ TAFE or University/Professional vs vocational jobs/

Is there anything else you would like to add? 


\section{Appendix 3: Interview schedule for staff members (started April 2013)}

The researcher used semi-structured interview questions to gather data and focussed the interview session on the following questions:

\section{Personal and Teaching experiences with Pacific Islander (PI) young people, communities}

- Tell me about your work at the school? What do you teach? How long have you been here? What sort of interactions have you had with PI at the School?

- Tell me about any interactions you have had with PI parents or communities? How did these interactions come about

- Have you had any interaction with PI families recently? What was it about? What do you think about the event?

- Is there one significant person or incident that you can remember /what caused it, what did you do about it/ what was the outcome?

\section{General information about PI}

- How many Pacific islanders attend the school? Which schools do they mostly come from? How many start at Year 8? How many leave after Year 10? How many go on to postcompulsory levels of schooling? How many finish Year 12 and gain VCE?

- How do PI present themselves in and outside of the classroom? Are they identifiable? How?

- Are there any PI young people you remember? What for?

- Are there any expectations from PI students? Are these different or similar to other students?

- How do other members of the school community see PI young people?

In class Interaction

- How do Pacific island learners in general interact with teaching and learning?

- What are their common patterns of engagement with the curriculum, with teachers and other learners within the classroom? Describe the general attitudes of PI families towards teaching and learning at the school?

- How do teachers view PI leaners in terms of their learning, response to class tasks and homework and overall engagement?

- What are teachers' general perceptions of PI learners' attitudes towards learning, cognitive abilities, attitudes towards schooling?

\section{Outside class Interaction}

- How do Pacific island learners in general interact with other students in the school? How do they interact with each other?

- How do other students view Pacific islanders at the school?

- Describe the general attitudes/behaviours of Pacific Island learners towards extra-curricular activities at this school? What activities do Pacific islander students generally participate in at school? Why do they participant in such events?

\section{Friendships and groups}

- In your view, are there differences between friendships made at primary and secondary schools? Why?

- At the schools, who do PI students mostly associate with? Inside the classroom, outside the classroom and in the community?

- What make these friendships possible?

- Are there structured ways for friendships to happen ie at school, within community groups, outside school etc?

- Are there different friendships formed at various stages of schooling/

- In your own practice, do you purposely set up opportunities for students to do work in particular groups? Can you share some experiences of your efforts to do formulate these groups?

\section{Learning or studying patterns of PI}


- Comment on the general performances/ achievement levels of PI learners at school, at the various level of schooling? Are there any changes in performance or achievement at the postcompulsory levels of schooling?

- In general, how do PI students respond to uniform, resource (books / pens) requirements?

- How do they respond to class room tasks or homework requirements?

- How can PI learners get the most benefit out of schooling, especially at post-compulsory education?

- What are some common characteristics/factors that have helped past or current PI learners become successful/ not so successful at the post-compulsory level of schooling?

- What are some strategies the school has used to assist PI learners achieve their education and career goals?

Transitions/ pathways/ contact post school?

- What are common pathways for these students prior to and post compulsory stages of schooling?

- How do Pacific island students respond to information about career options, pathways and further education?

- Does the school maintain any contact with students after school? Are there any PI that maintain contact with the school? Why and with whom?

Home support and conclusion

- How would you describe the level of support that PI students receive at home / from family? How do you think home support could be improved?

- Would it be possible for you to keep a journal between now and the end of 2013 that records interactions/critical incidents you have experienced or observed with PI students ie what was the issue/ problem, who initiated the interaction, how was it solved? How did the school, the student and her/his parents help to resolve the situation? How can this be a lesson for the future? 